\title{
Implementasi Sistem Kontrol Fuzzy Pada Robot Lengan Exoskeleton
}

\author{
Wayan Reza Yuda Ade Prasetya ${ }^{1)^{*}}$, I Wayan Widhiada ${ }^{2)}$ \\ ${ }^{1)}$ Program Studi magister Teknik Mesin, Fakultas Teknik, Universitas Udayana \\ Kampus Sudirman, Bali 80232 \\ Email : wayan unnes@yahoo.co.id \\ 2) Jurusan Teknik Mesin, Fakultas Teknik, Universitas Udayana \\ Kampus Bukit Jimbaran, Bali 80362 \\ Email : widhiwyn@yahoo.com
}

doi: https://doi.org/10.24843/METTEK.2018.v04.i02.p04

\begin{abstract}
Abstrak
Manusia ingin dilahirkan dalam kehidupan yang sempurna, baik jasmani maupun rohani. Tetapi dalam kenyataannya, manusia jauh dari sempurna. Salah satu ketidaksempurnaan yaitu kelumpuhan pada lengan. Penelitian yang sekarang berkembang yaitu robot exoskeleton. Exoskeleton merupakan struktur pendukung dari bagian luar tubuh. Robot ini memiliki aplikasi prospektif untuk rehabilitasi atau alat bantu. Sistem kontrol exoskeleton yang sukses bergantung pada pemahaman yang lebih baik dalam biomekanik gerak tubuh manusia dan mekanisme sensorik yang juga merupakan masalah penting dalam interaksi fisik manusia-robot. Robot siku lengan yang dikembangkan oleh Thomas menggunakan servo motor sebagai aktuator. Semakin berat beban, semakin besar torsi servo tersebut. Di Indonesia tidak dijumpai servo dengan torsi tinggi. Hanya motor DC yang banyak di pasaran. Untuk menekan biaya pengembangan robot lengan exoskeleton, penelitian menggunakan motor DC. Sistem kontrol diperlukan untuk membuat sebuah motor DC bergerak seperti layaknya motor servo. Sistem kontrol logika Fuzzy paling tepat untuk mengontrol motor DC. Sebuah prototype robot lengan exoskeleton dibuat. Motor DC sebagai penggerak lengan robot. Sistem kontrol Fuzzy pada robot dibuat menggunakan software SIMULINK/MATLAB. Gerak robot dibatasi dari $0^{\circ}$ sampai $90^{\circ}$. Sistem akan diuji menggunakan SIMULINK/MATLAB dan dilakukan dengan interface prototype exoskeleton. SIMULINK/Matlab memudahkan pembuatan Logika Fuzzy yang dapat mengontrol Motor DC bergerak layaknya motor servo. Data Parameter respon transient dari hasil pengujian prototype selama 20 detik, waktu tunda $(\mathrm{td})=1.16$, waktu naik $(\operatorname{tr})=1.98$, waktu puncak $(\mathrm{tp})=2.16$. Data parameter sistem kontrol Logika Fuzzy lebih baik daripada sistem kontrol sederhana yang dibuat.
\end{abstract}

Kata Kunci : Sistem Kontrol Fuzzy, Exoskeleton, Prototype

\section{Abstract}

Humans want to be born in a perfect life, both physically and spiritually. But in reality, humans are far from perfect. One of the imperfections is arm paralysis. The current study is an exoskeleton robot. The exoskeleton is the supporting structure of the outer part of the body. This robot has a prospective application for rehabilitation or aids. Successful exoskeleton control systems rely on better understanding of the biomechanics of human body motion and the sensory mechanisms that are also important problems in human-robot physical interactions. The elbow arm robot developed by Thomas uses servo motors as actuators. The heavier the load, the

${ }^{*}$ Penulis korespondensi

Email: wayan unnes@yahoo.co.id 
greater the servo torque. In Indonesia there is no servo with high torque. Only DC motors are in the market. To reduce the development cost of robotic arm of exoskeleton, research using DC motor. A control system is needed to make a DC motor move like a servo motor. Fuzzy logic control system is most appropriate for control of DC motors. A prototype of an exoskeleton robot arm is made. DC motor as a actuator robot. Fuzzy control system on the robot is made using SIMULINK / MATLAB software. Robot motion is limited from $0^{\circ}$ to $90^{\circ}$. The system will be tested using SIMULINK / MATLAB and done with prototype exoskeleton interface. SIMULINK / Matlab facilitate the manufacture of Fuzzy Logic that can control the motion of DC motors like servo motors. Data Parameter transient response from prototype test result for 20 seconds, Delay time $(t d)=1.16$, Rise time $(t r)=1.98$, Peak time $(t p)=2.16$. Data parameters Fuzzy Logic control system is better than the simple control system created.

Keywords: Fuzzy Control System, Exoskeleton, Prototype

\section{PENDAHULUAN}

Salah satu ketidaksempurnaan dari manusia yaitu kelumpuhan pada lengan. Kelumpuhan pada lengan merupakan sebuah gangguan fungsi gerak pada lengan manusia. Gangguan fungsi tersebut dapat diakibatkan oleh kelainan genetik, kecelakaan atau penyakit.

Penelitian dikembangkan untuk membuat suatu alat bantu yang digunakan mengatasi gangguan fungsi tersebut. Penelitian robotika yang dikembangkan yaitu robot exoskeleton. Exoskeleton adalah struktur pendukung dari bagian luar tubuh [2]. Robot exoskeleton memiliki aplikasi prospektif untuk rehabilitasi atau alat bantu.

Robot ini dapat membantu pasien yang lemah dan lumpuh untuk mendapatkan kembali kehidupan mandiri dengan kemampuan untuk melakukan aktivitas sehari-hari [3]. Robot siku lengan yang dikembangkan oleh Thomas A. Evison menggunakan servo motor [5]. Input dari servo tersebut yaitu sensor berat (load cell sensor). Servo motor yang digunakan yaitu Dynamixel MX-28T yang mempunyai torsi 2,5 Nm. Semakin berat beban yang digerakkan oleh motor servo tersebut, semakin besar pula torsi motor DC yang dibutuhkan. Maka dari itu, harga untuk sebuah servo dengan torsi yang besar sangatlah tinggi. Harga robot lengan exoskeleton menjadi menjadi mahal. Sehingga diperlukan pengembangan robot siku lengan exoskeleton dengan biaya murah. Dalam penelitian ini untuk mengembangkan robot lengan exoskeleton dengan biaya murah, maka peneliti menggunakan motor DC sebagai pengganti untuk motor servo. Untuk mengontrol motor DC bergerak seperti motor servo maka diperlukan suatu sistem kontrol. Sistem kontrol logika Fuzzy paling tepat untuk mengontrol motor DC [6]. Kontroler fuzzy menyediakan metodologi formal untuk merepresentasikan, memanipulasi, dan menerapkan pengetahuan heuristik manusia tentang bagaimana mengendalikan sistem [7]. Maka dari itu penulis akan menganalisa implementasi sistem logika fuzzy pada robot lengan exoskeleton yang menggunakan motor DC.

\section{DASAR TEORI}

\subsection{Exoskeleton}

Exoskeleton yaitu rangka external yang dipasang pada anggota tubuh untuk membantu gerak ataupun untuk melindungi bagian tubuh. Rangka ini didukung oleh sistem motor listrik, pneumatik, tuas, hidraulika, atau kombinasi teknologi yang memungkinkan gerakan anggota badan dengan kekuatan dan meningkatkan daya tahan.

Lengan exoskeleton adalah struktur mekanis luar antropomorfik yang memungkinkan pengalihan tenaga mekanik dari struktur exoskeleton ke lengan manusia [9]. Perangkat seperti ini memungkinkan dilakukannya rehabilitasi fisioterapi dan lengan exoskeleton dimaksudkan untuk memberi terapi pasif kepada korban stroke agar tidak terjadi spastisitas 
pada persendian [10]. Uji klinis telah membuktikan bahwa terapi robot pasif menghasilkan perbaikan rehabilitasi gerakan bahu dan siku pada pasien hemiparesis spastik dibandingkan dengan fisioterapi tradisional [11].

\subsection{Sistem Kontrol}

Syarat utama untuk sistem kontrol yaitu sistem kontrol tersebut harus stabil (steady state). Selain itu sistem kontrol harus mempunyai respon yang baik. Kecepatan respon harus cepat dan mempunyai peredam yang layak. Sistem kontrol harus mampu meminimalisir error sama dengan nol atau pada nilai yang di toleransi.

\subsection{Logika Fuzzy}

Logika Fuzzy menunjukkan suatu logika yang didasari pada studi metode dan prinsip pemahaman manusia [12:58]. Tujuan utamanya adalah untuk memberikan fondasi untuk perkiraan penalaran menggunakan proposisi yang tidak tepat berdasarkan teori himpunan fuzzy, dengan cara yang mirip dengan penalaran klasik menggunakan proposisi yang tepat berdasarkan teori himpunan klasik [12:66].

Logika fuzzy ditemukan oleh Prof. Lotfi A. Zadeh sejak tahun 1965. Sistem logika fuzzy (FLS) unik karena mampu menangani data numerik dan pengetahuan akademis secara bersamaan [14].

Pada prinsipnya algoritma fuzzy mencoba menjawab keterbatasan-keterbatasan yang dimiliki oleh struktur logika biner Boolean yang hanya memiliki dua kondisi pernyataan yaitu benar (true) atau salah (false). Algoritma fuzzy mencoba menjembatani kondisi-kondisi yang tidak hanya bisa diselesaikan dengan pernyataan "ya" atau "tidak" dan juga mendeskripsikan kondisi-kondisi pertengahan, kondisi diantara ya dan tidak kedalam formulasi matematis [13]. Secara singkat, logika fuzzy memungkinkan istilah linguistik yang tidak tepat seperti:

- predikat fuzzy: tua, langka, berat, mahal, tinggi, cepat

- Pengukur fuzzy: banyak, sedikit, biasanya, hampir, sedikit, banyak

- nilai kebenaran fuzzy: sangat benar, benar, tidak mungkin benar, kebanyakan salah, salah, pasti salah

Dalam menganalisa dan mendesain system kontrol, kita harus mempunyai suatu dasar perbandingan performansi system kontrol. Dasar ini dapat disusun dengan menetapkan sinyal-sinyal uji tertentu dan membandingkan respon berbagai sistem terhadap sinyal-sinyal masukan ini. Setelah sistem kontrol di disain berdasarkan sinyal uji, performansi system dalam memberikan respon terhadap masukan yang sebenarnya biasanya memuaskan. Penerapan sinyal uji memudahkan untuk menyerupakan performansi semua sistem dengan dasar yang sama.

\subsection{Analisa Transient-Response}

Perilaku respon transien diuji dalam analisa sistem kontrol. Seperti waktu yang diperlukan untuk mencapai keadaan tunak yang baru dan harga kesalahan pada saat mengikuti sinyal masukan maupun perilaku keadaan tunaknya. Hal yang biasa dilakukan untuk membandingkan karakteristik respon yaitu memasukkan keadaan awal standar bahwa sistem awal dalam keadaan diam sehingga output dan semua turunan waktunya pada awal respon bernilai nol.

Untuk mencari karakteristik respon dari sistem kontrol terhadap referensi, biasanya dipakai parameter berikut :

1. Delay time (waktu untuk tunda), td. Yaitu waktu yang dibutuhkan respon mencapai setengah harga akhir yang pertama kali.

2. Rise time (waktu untuk naik), tr. Yaitu waktu yang dibutuhkan respon naik dari 0 sampai $100 \%$ dari harga akhirnya. 
3. Peak time (waktu untuk puncak), tp. Yaitu waktu yang dibutuhkan respon untuk mencapai puncak lewatan pertama kali.

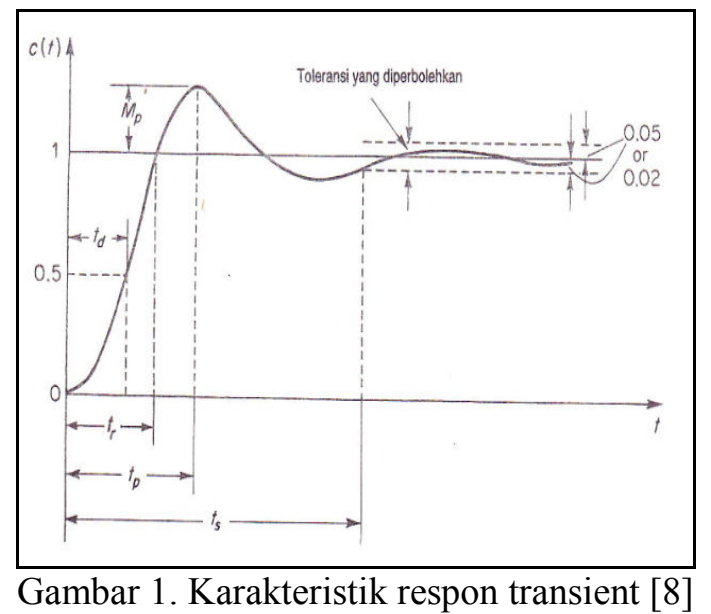

\section{METODE PENELITIAN}

Metode penelitian eksperimental digunakan untuk mendapatkan hasil uji dari sistem. Pembuatan Prototype robot exoskeleton dilakukan terlebih dahulu. Pemilihan motor DC menggunakan motor DC sparepart mobil karena motor tersebut mempunyai torsi yang besar.

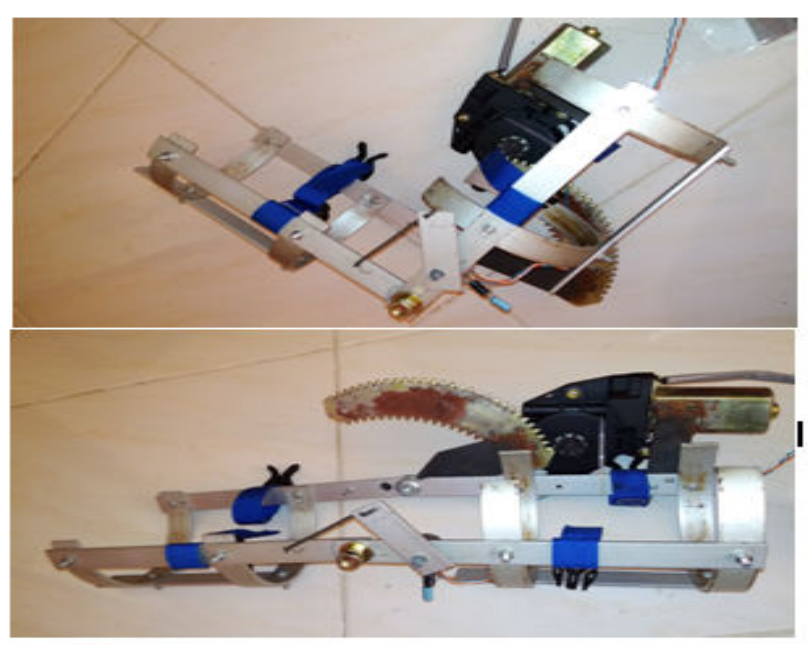

Logika Fuzzy dibuat dalam dalam program MATLAB. peneliti dapat memetakan voltase yang masuk ke motor DC dan memasukkan toleransi dari sudut gerak lengan. Putaran motor akan diatur dengan pengaturan tegangan oleh logika ini. Input yang dipakai yaitu selisih dari input sistem dengan sudut aktual gerak lengan. Didalam MATLAB, logika fuzzy dibuat terlebih dahulu. Member Function logika fuzzy dapat dilihat dalam gambar (3). Output logika fuzzy dapat dilihat dalam gambar (4). Skema Rule dalam logika fuzzy juga dapat dilihat dalam gambar (5). 


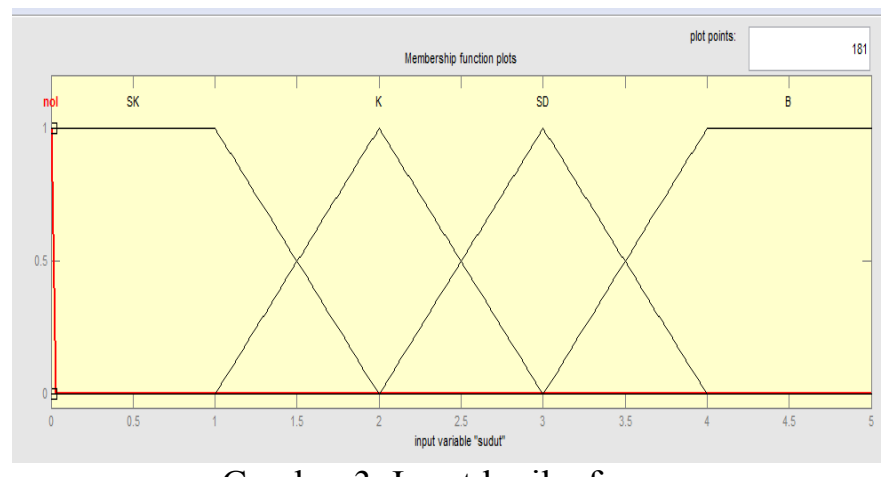

Gambar 3. Input logika fuzzy

Input sudut yang dipetakan dalam logika fuzzy yaitu antara sudut $0^{\circ}$ sampai dengan sudut $5^{\circ}$. Fungsi Keanggotaan input dibagi menjadi 5 kategori yaitu Nol, SK, K, SD, dan B.

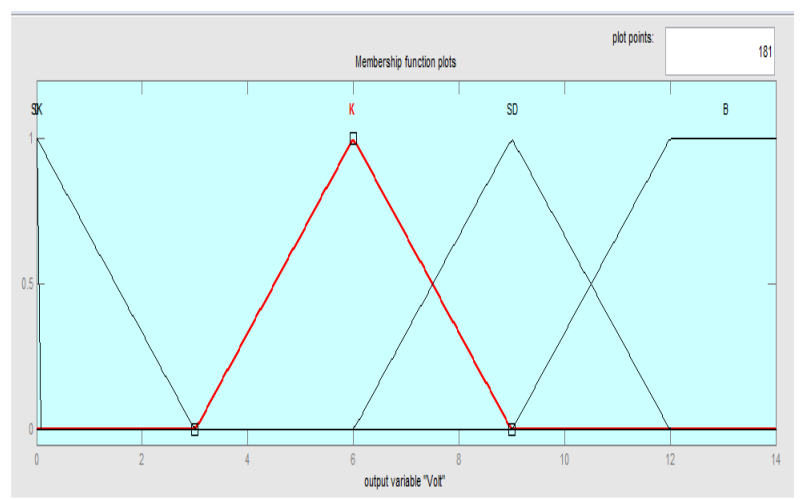

Gambar 4. Output logika fuzzy

Output logika fuzzy yaitu voltase dari 0-12 Volt. Fungsi keanggotaan output dari logika fuzzy dibagi menjadi 5, yaitu Nol, SK, K, SD, dan B.

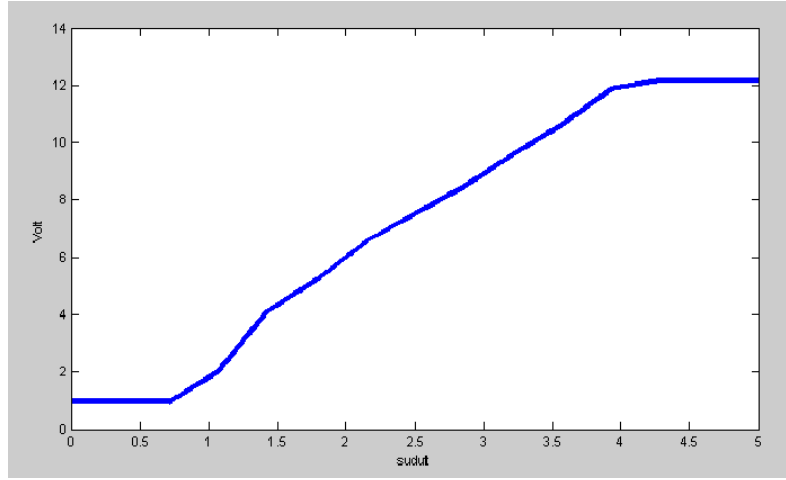

Gambar 5. Rule logika fuzzy

Setelah dipasangkan rule logika fuzzy antara MF input dan MF Output, didapatkan grafik pemetaan antara sudut dengan voltase. Ketika error sudut bernilai lebih dari 4, maka voltase yang diberikan 12 volt. Ketika nilai error sudut kurang dari 4, maka voltase yang diberikan mengikuti nilai error sampai mendekati nol.

Logika fuzzy dibuat untuk mengontrol suatu sistem kontrol robot exoskeleton. Sistem yang dibuat juga menggunakan program SIMULINK / MATLAB. Sistem kontrol Motor DC ini meniru sistem kontrol motor servo yaitu mengatur dan memastikan posisi sudut yang dibentuk oleh output poros motor sesuai dengan input sudut yang diberikan. Dalam program SIMULINK / MATLAB, sistem kontrol berbentuk diagram blok. Sistem kontrol logika fuzzy yang dibuat seperti gambar (6). Batas toleransi Error yang muncul yaitu $<2$, dikarenakan gap antara gear-gear yang ada dalam motor tersebut. 


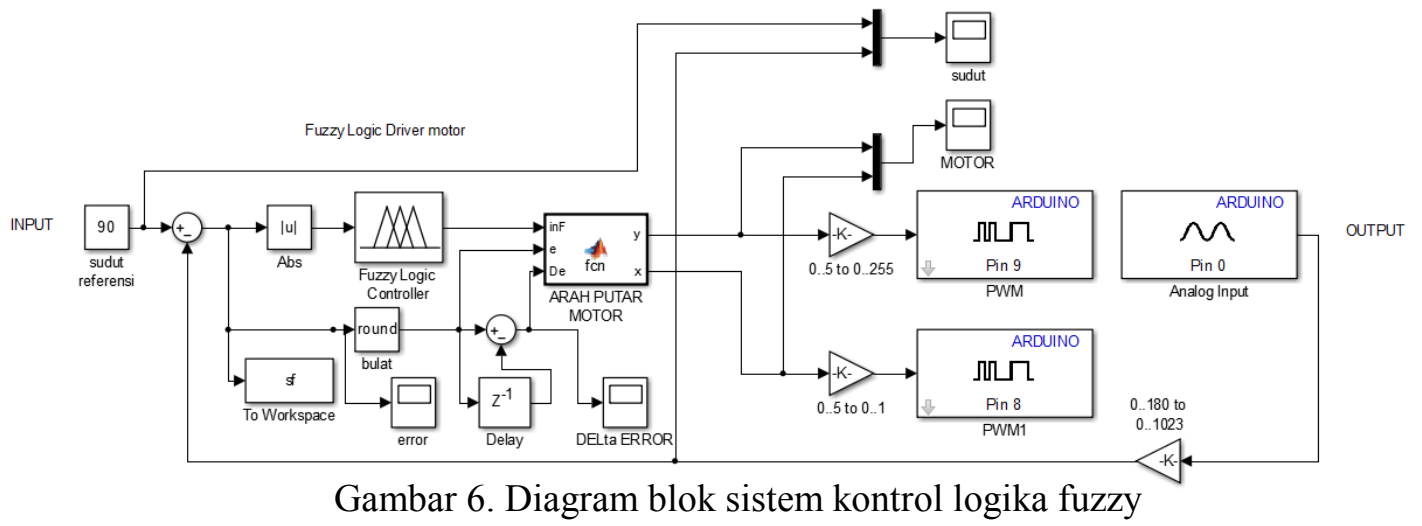

\section{HASIL DAN PEMBAHASAN}

Dengan melakukan interface antara robot dan komputer didapatkan hasil respon berupa grafik gerakan aktual dari robot exoskeleton.

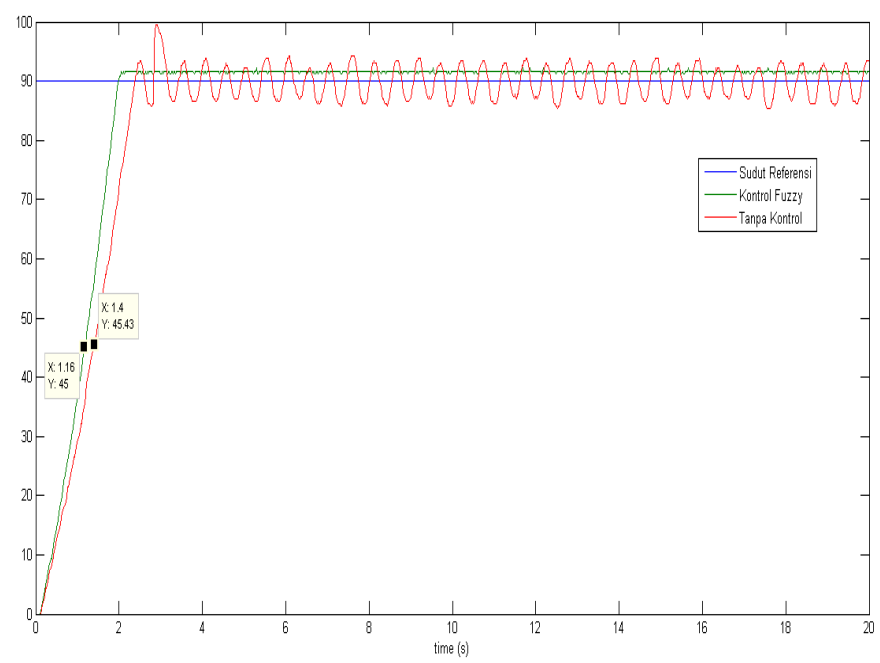

Gambar 7. Respon Gerak Robot

Perbandingan respon gerak robot yang menggunakan kontrol logika fuzzy dan tidak menggunakan kontrol logika fuzzy dapat dilihat dalam tabel berikut.

Tabel 1. Respon transien robot exoskeleton

\begin{tabular}{c|c|c}
\hline \multicolumn{3}{c}{ Transient-Response Robot Exoskeleton } \\
\hline & Fuzzy & Non-Fuzzy \\
\hline $\mathrm{td}$ & 1.16 & 1.4 \\
\hline $\mathrm{tr}$ & 1.98 & 2.38 \\
\hline $\mathrm{tp}$ & 2.16 & 2.88 \\
\hline
\end{tabular}

Melihat dari hasil respon gerak, robot yang menggunakan sistem kontrol logika fuzzy lebih responsif. Waktu yang diperlukan robot bergerak mencapai $90^{\circ}$ yaitu $1,98 \mathrm{~s}$. Respon robot stabil setelah melawati waktu puncak 2,16s. Error yang muncul yaitu 1,715. Error masih dalam batas toleransi. Logika Fuzzy di dalam sistem ini berperan memetakan voltase untuk gerak motor dari input error sudut. Semakin besar error sudut yang terjadi, semakin besar pula voltase yang masuk ke motor. Sebaliknya, semakin kecil error, semakin kecil pula voltase yang masuk ke motor. Sehingga membuat gerak robot lebih responsif dan stabil ketika mencapai sudut referensi yang diberikan. 
Sistem yang tidak menggunakan logika fuzzy memiliki waktu gerak yang lebih lambat karena voltase yang masuk ke motor tetap. Dengan tetapnya voltase berakibat nilai error melebihi nilai toleransi error. Error yang besar menjadikan respon gerak motor tidak stabil dan menjadikan osilasi, dapat dilihat dalam gambar grafik error.

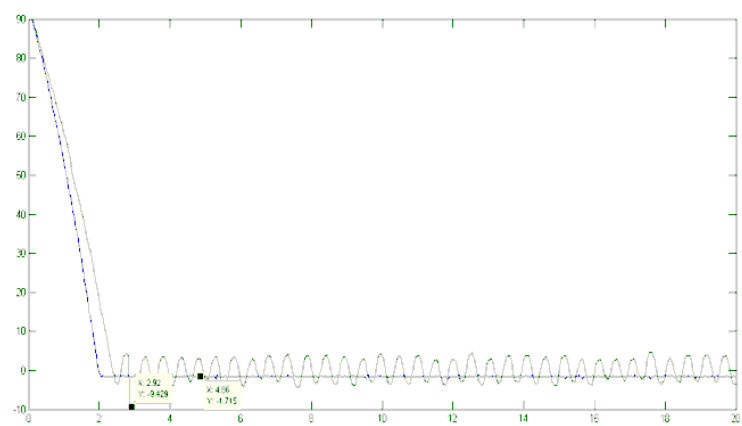

Gambar 8. Error Gerak Robot Exoskeleton

\section{SIMPULAN}

Berdasarkan penelitian mengenai Analisa Respon Sistem Kontrol Fuzzy pada Robot Lengan Exoskeleton, dapat diambil beberapa kesimpulan yaitu :

1. Sistem Kontrol Logika Fuzzy yang digunakan pada motor DC dapat menggantikan kerja motor Servo.

2. SIMULINK/Matlab memudahkan pembuatan Logika Fuzzy yang dapat mengontrol Motor DC bergerak layaknya motor servo

3. Sistem Logika Fuzzy memiliki waktu tunda $1,16 \mathrm{~s}$, waktu naik $1.98 \mathrm{~s}$ dan waktu puncak 2.16s. nilai error yang muncul yaitu 1,715 dan masih dalam batas toleransi.

\section{DAFTAR PUSTAKA}

[1] Yunus, mohammad. Perencanaan Dan Pembuatan Simulasi Alat Bantu Gerak Lengan Tangan Bagi Penderita Kelumpuhan. Universitas Muhammadiyah, Malang. 2007.

[2] Mark Novak Cornel College PHY312 December 2011 Professor Derin Sherman

[3] Lelai Zhou, Yibin Li , Shaoping Bai. A Human-Centered Design Optimization Approach For Robotic Exoskeletons Through Biomechanical Simulation. Department of Mechanical and Manufacturing Engineering, Aalborg University, Aalborg, Denmark.

[4] W. Gallagher, M. Ding, J. Ueda. Relaxed Individual Control Of Skeletal Muscle Forces Via Physical Humancrobot Interaction. Multibody System Dynamics 30(1)(2013)77-99.

[5] Thomas A. Evison. The Design, Development And Control Of A Motorised Elbow Exoskeleton For Introducing Perturbations As A Bio-Medical Research Tool. School of Electrical, Computer and Telecommunications Engineering. University of Wollongong. 2006.

[6] Mohamad Nadhif. Aplikasi Fuzzy Logic Untuk Pengendali Motor Dc Berbasis Mikrokontroler Atmega8535 Dengan Sensor Photodioda. UNIVERSITAS NEGERI SEMARANG. 2015.

[7] Passino KM, Yurkovich S. Fuzzy Control. Addison-Wesley Long-man, Inc. 1998.

[8] Ogata, Katsuhiko. 1996. Teknik Kontrol Automatik. Jakarta : Erlangga

[9] S. Panich. Kinematic Analysis Of Exoskeleton Suit For Human Arm. Journal of Computer Science, vol. 6, pp. 1272-1275, . 2010. 
[10] Dasheek Naidu, Riaan Stopforth, Glen Bright and Shaniel Davrajh. A Portable Passive Physiotherapeutic Exoskeleton.

[11] J W. McDonald and C. Sadowsky. Spinal-Cord Injury. The Lancet, vol. 359, pp.417-425, 02February. 2002.

[12] Guanrong Chen, Trung Tat Pham. Fuzzy Sets, Fuzzy Logic, And Fuzzy Control Systems. University of Houston, Houston, Texas. 2001.

[13] Kartina Diah KW,ST, , Zulfa Noviardi. Penerapan Inferensi Fuzzy Untuk Kendali Suhu Ruangan Pada Pendingin Ruangan (Ac). Politeknik Caltex Riau Pekanbaru. 2010 . 